\title{
Proposal for a harmonised PBT identification across different regulatory frameworks
}

\author{
Caren Rauert ${ }^{1 *}$, Anton Friesen², Georgia Hermann³ ${ }^{3}$ Ulrich Jöhncke ${ }^{4}$, Anja Kehrer ${ }^{2}$, Michael Neumann ${ }^{4}$, Ines Prutz ${ }^{5}$, \\ Jens Schönfeld ${ }^{5}$, Astrid Wiemann ${ }^{5}$, Karen Willhaus ${ }^{2}$, Janina Wöltjen ${ }^{3}$ and Sabine Duquesne ${ }^{3}$
}

\begin{abstract}
European regulatory frameworks for chemicals (i.e. registered under REACH, plant protection products (PPPs), biocides, human and veterinary medicinal products) require that substances undergo an assessment to identify whether they are persistent $(P)$, bioaccumulative $(B)$ and toxic $(T)$, or very persistent ( $V P$ ) and very bioaccumulative (vB), i.e. to identify them as PBT substances or vPvB substances according to their properties. We screened current practices, evaluated possibilities and made a proposal for a harmonised assessment. Our proposal assumes that it should be possible to identify PBT and VPvB substances on the basis of the data available according to the requirements of the respective legal frameworks. For substances registered as PPPs and mostly also biocides and medicinal products, a 'definitive assessment' is often possible. Within REACH, the registrant has to provide all information necessary for PBT assessment regardless of the yearly tonnage of chemicals. But in cases of limited data availability, we suggest using a weight of evidence approach to account for such differences in data availability and type of data across different frameworks and to make use of valuable additional information. We propose to base the evaluation of persistence on degradation half-lives and to normalise a number of parameters (e.g. type of kinetics used, temperature). But further work is needed, e.g. for deriving Deg $T_{50}$ for water and sediment compartments. For the B-criterion, information other than BCF in fish could be considered and more information related to bioaccumulation processes should be gathered (e.g. in species other than fish, different uptake routes). Testing for T identification is focused on standard aquatic species but could also be complemented by e.g. information from other species. Information such as those read-across from structurally related substances and QSAR are often of importance for screening assessments. The aim of PBT and vPvB identification is to reliably target the problematic substances, with as few false negatives or positives as possible, regardless of the regulatory framework. Each aspect was thus considered in the context of the others for a final balanced decision. As the need for conservatism is interpreted differently under the various frameworks, harmonizing this identification is a challenging task.
\end{abstract}

Keywords: PBT identification; Persistence; Bioaccumulation; Toxicity; REACH; Plant protection products; Biocides; Human medicinal products; Veterinary medicinal products; Harmonisation; Regulatory framework

\section{Background}

The different European substance regulations (e.g. REACH [1], plant protection products regulation [2], biocidal products regulation [3], human and veterinary medicinal products regulations $[4,5])$ have all recognised that substances that are either persistent (P), bioaccumulative (B) and toxic (T) (PBT substances) or very persistent (vP) and very bioaccumulative (vB) (vPvB substances) must be

\footnotetext{
* Correspondence: caren.rauert@uba.de

${ }^{1}$ Section International Chemicals Management, Federal Environment Agency (UBA), Wörlitzer Platz 1, 06844 Dessau-Roßlau, Germany

Full list of author information is available at the end of the article
}

considered as hazardous for the environment due to their potential for eliciting long-term adverse effects. The goal of preventing exposure of humans and the environment to PBT and $\mathrm{vPvB}$ substances is thus shared among all EU-based regulatory frameworks. In a comparison between different European and International regulations, Moermond et al. [6] reported that there are differences in how this goal is achieved, not only regarding technical criteria but also conceptual criteria (e.g. regulatory consequences for PBT and $\mathrm{vPvB}$ substances).

In terms of numerical criteria, the identification of PBT and $\mathrm{vPvB}$ substances is based on substance properties 
which are addressed by the same trigger values in all European substance regulations (see Table 1).

Therefore, it could be assumed that the identification of a PBT or $\mathrm{vPvB}$ substance should be independent of both the use of the substance and the regulatory framework under which it is assessed. However, the decision on whether a substance fulfils the PBT or $\mathrm{vPvB}$ criteria not only depends on substance properties, but also on the framework under which the substance is evaluated. For substances whose properties are near the trigger values, this decision may differ due to differences between the different legal frameworks in

(i) The assessment procedures,

(ii) The interpretation of $\mathrm{PBT} / \mathrm{vPvB}$ criteria,

(iii) Available data within the assessment process (see next subsection), and

(iv) The regulatory consequences

Although based on the same principle (i.e. avoiding emissions of potentially harmful substances to the environment), the mandatory measures imposed by regulation for a substance identified as a PBT or vPvB vary between the different regulatory frameworks:

- For substances registered under REACH, the revised Annex XIII [7] not only gives the criteria but also the information relevant for the screening and assessment of $\mathrm{P}, \mathrm{vP}, \mathrm{B}, \mathrm{vB}$ and $\mathrm{T}$ properties. Also, ECHA provides extensive guidance on $\mathrm{PBT} / \mathrm{vPvB}$ assessment $[8,9]$. Substances of very high concern (SVHC) (e.g. PBT/vPvB) are included in the 'candidate list' for authorisation, based on the outcome of the scientific assessment of intrinsic properties. Substances on the 'candidate list' can then be prioritised for authorisation and finally listed in Annex XIV of the REACH regulation. Some substances may be listed with specific exemptions that do not require authorisation. For each substance included in Annex XIV, a deadline will be set after which use of that substance in the EU must stop (known as the 'sunset date'), unless authorized by the European Commission.

- The EU Biocidal Products Regulation [3] refers to Annex XIII of REACH [7] and to the ECHA guidance for $\mathrm{PBT} / \mathrm{vPvB}$ assessment $[8,9]$. However, for biocides, generally no authorisation will be granted for products containing substances identified as PBT or vPvB. Additionally, biocides that fulfil two of the three criteria are flagged as candidates for substitution and are subjected to a comparative assessment.

- For the assessment of veterinary medicinal products, guidance has been developed by the European Medicines Agency [10], which also refers to ECHA guidance $[8,9]$. A benefit-risk analysis is conducted in support of the decision on whether to authorise the substance or not [5]. In this context, an identification as a PBT substance is generally regarded as a serious concern.

- For medicinal products for human use (which are usually emitted via sewage treatment plants), no restrictions are envisaged as human health is prioritised over environmental issues [4]. ECHA guidance $[8,9]$ is used for the assessment.

- By contrast, the PPP Regulation [2] simply stipulates the $\mathrm{PBT} / \mathrm{vPvB}$ criteria, oblivious to any other guidance. As for biocides, no authorisation will be granted for those substances identified as PBT or vPvB. Additionally, PPPs that fulfil two of the three criteria are flagged as candidates for substitution and are subjected to a comparative assessment, as is the case for biocides. The draft guidance developed by DG Sanco [11] focuses primarily on the identification of candidates for substitution.

Although the substances differ in their properties, uses, exposure pathways and regulatory consequences,

Table 1 PBT and vPvB criteria across the various European substance regulations

\begin{tabular}{|c|c|c|}
\hline Criterion & PBT identification & vPvB identification \\
\hline \multirow[t]{5}{*}{ Persistence } & - Half-life (degradation) > 60 days in marine water, or & \multirow{2}{*}{$\begin{array}{l}\text { - Half-life (degradation) > } 60 \text { days in marine, fresh or } \\
\text { estuarine water, or }\end{array}$} \\
\hline & - Half-life (degradation) > 40 days in fresh or estuarine water, or & \\
\hline & - Half-life (degradation) > 180 days in marine sediment, or & \multirow{2}{*}{$\begin{array}{l}\text { - Half-life (degradation) > } 180 \text { days in marine, fresh or } \\
\text { estuarine sediment, or }\end{array}$} \\
\hline & - Half-life (degradation) > 120 days in fresh or estuarine sediment, or & \\
\hline & - Half-life (degradation) > 120 days in soil & - Half-life (degradation) > 180 days in soil \\
\hline Bioaccumulation & $\cdot \mathrm{BCF}>2,000 \mathrm{~L} / \mathrm{kg}$ & $\cdot \mathrm{BCF}>5,000 \mathrm{~L} / \mathrm{kg}$ \\
\hline \multirow[t]{3}{*}{ Toxicity } & - NOEC (long-term) < 0.01 mg/L for marine or freshwater organisms, or & \multirow[t]{3}{*}{ - Not applicable } \\
\hline & $\begin{array}{l}\text { - Classification as carcinogenic (category } 1 \text { or } 2 \text { ), mutagenic (category } \\
1 \text { or } 2 \text { ), or toxic for reproduction (category } 1 \text { or } 2 \text { ), or }\end{array}$ & \\
\hline & $\begin{array}{l}\text { - Other evidence of chronic toxicity, as identified by the classifications } \\
\text { STOT RE } 1 \text { or STOT RE } 2 \text { pursuant to Regulation (EC) No 1272/2008 }\end{array}$ & \\
\hline
\end{tabular}


the outcome of a PBT/vPvB assessment should not depend on the framework under which they are evaluated, since the protection goals do not differ. This will avoid situations where a substance with different uses is identified as a PBT substance under one regulation, and not under another. This is relevant because, for example, many biocides are also used as PPPs or veterinary medicinal products. Since regulatory authorities should aim at making predictable and consistent decisions, a strategy for harmonised PBT identification across the different frameworks is needed. The focus of this paper is on the assessment procedure; it proposes a reasonable interpretation of the available data while considering not only substance properties but also keeping in mind the regulatory consequences.

Dealing with differences in data requirements and data availability between regulatory frameworks

For substances registered as plant protection products (PPPs), as well as most biocides and medicinal products, requirements for environmental risk assessment usually include sufficient information for $\mathrm{PBT} / \mathrm{vPvB}$ identification. Therefore, a 'definitive assessment' based on a direct comparison to the trigger values (see Table 1) of the three criteria should be possible in most cases.

For chemicals registered under $\mathrm{REACH}$, data requirements depend on the quantities which are manufactured or imported per year; for high production volume (HPV) chemicals, more data has to be provided, and for substances below $10 \mathrm{t} / \mathrm{a}$, only a basic data set is mandatory. Table 2 provides an overview of test requirements for persistence. The registrant also has to provide all information needed for $\mathrm{PBT} / \mathrm{vPvB}$ assessment regardless of the tonnage manufactured or imported annually. However, the necessary information is not always included in the dossiers so a direct comparison of measured data with the criteria is not always possible. Unfortunately, in many cases, registrants submitted dossiers which show deficiencies and do not comply with the requirements of REACH or the Technical Guidance Document, e.g. necessary tests are missing $[12,13]$. In such cases, only a 'screening assessment' can be performed. In such an assessment screening information such as that listed in Annex XIII of REACH [7] should be considered; this should be supplemented by data from non-standardised tests and from the literature, by information on relevant endpoints based on quantitative structure-activity relationships (QSARs) if adequately documented as well as by read-across from structurally related substances or grouping approaches. Only if the available information is considered unreliable or insufficient and/or does not permit a conclusion on each criterion to be drawn with sufficient confidence, additional testing will be necessary.

Because of the large differences in data requirements across the different frameworks and type of data (e.g. QSARs, non-standardised tests), we recommend considering all available information in a weight of evidence (WoE) approach - as suggested in REACH (Annex XI 1.2 of [1]). The WoE approach means that all available information is assessed through expert judgement for its suitability and reliability, and relative weights are assigned (e.g. quality of the data, consistency of results and/or data, nature and severity of effects, relevance of the information for the given regulatory endpoint). The use of this WoE approach depends on the amount of information needed, the importance of the decision to be taken, and

Table 2 Persistence testing requirements under the various European substance regulations

\begin{tabular}{|c|c|c|c|c|c|}
\hline & $\begin{array}{l}\text { Test on ready } \\
\text { biodegradability } \\
\text { (OECD 301) }\end{array}$ & $\begin{array}{l}\text { Laboratory degradation } \\
\text { simulation test in soil } \\
\text { (OECD 307) }\end{array}$ & $\begin{array}{l}\text { Laboratory degradation } \\
\text { simulation test in a } \\
\text { water-sediment system } \\
\text { (OECD 308) }\end{array}$ & $\begin{array}{l}\text { Laboratory degradation } \\
\text { simulation test in water } \\
\text { (OECD 309) }\end{array}$ & Field degradation test \\
\hline PPPs & Required & $\begin{array}{l}\text { Required in four soils if } \\
\text { not readily biodegradable }\end{array}$ & $\begin{array}{l}\text { Required in two test } \\
\text { systems if not readily } \\
\text { biodegradable }\end{array}$ & $\begin{array}{l}\text { Required if not readily } \\
\text { biodegradable }\end{array}$ & $\begin{array}{l}\text { Required if } \mathrm{Deg}_{50 \mathrm{ab}} \\
>60 \text { days }\left(20^{\circ} \mathrm{C}, \mathrm{pF} 2\right)\end{array}$ \\
\hline $\begin{array}{l}\text { Human } \\
\text { medicinal } \\
\text { products }\end{array}$ & Required & $\begin{array}{l}\text { Required in four soils if } \\
\text { not readily biodegradable } \\
\text { and } K O C>10,000 \mathrm{~L} / \mathrm{kg}\end{array}$ & $\begin{array}{l}\text { Required in two test } \\
\text { systems if not readily } \\
\text { biodegradable }\end{array}$ & Not required & Not required \\
\hline $\begin{array}{l}\text { Veterinary } \\
\text { medicinal } \\
\text { products }\end{array}$ & Not required & Required in four soils & $\begin{array}{l}\text { Required in two test } \\
\text { systems for aquaculture or } \\
\text { if risk is identified for } \\
\text { aquatic organism }\end{array}$ & Not required & Not required \\
\hline Biocides & Required & $\begin{array}{l}\text { Required in four soils if } \\
\text { not readily biodegradable } \\
\text { and/or depending on } \\
\text { emission pathway }\end{array}$ & $\begin{array}{l}\text { Required in two test } \\
\text { systems if not readily } \\
\text { biodegradable depending } \\
\text { on substance properties } \\
\text { and emission pathway }\end{array}$ & $\begin{array}{l}\text { Required if not readily } \\
\text { biodegradable depending } \\
\text { on substance properties } \\
\text { and emission pathway }\end{array}$ & 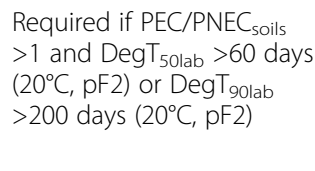 \\
\hline $\begin{array}{l}\text { Chemicals } \\
\text { (REACH) }\end{array}$ & $\begin{array}{l}\text { Required for all } \\
\text { substances }>10 \mathrm{t} / \mathrm{a}\end{array}$ & \multicolumn{3}{|c|}{$\begin{array}{l}\text { One simulation study in the 'compartment of concern' required for all } \\
\text { substances }>100 \text { t/a if not readily biodegradable }\end{array}$} & Not required \\
\hline
\end{tabular}


the likelihood and consequences of taking a wrong decision [14]. The WoE approach also has the advantage, such that it uses valuable additional information whose submission is not mandatory (e.g. field data, alternative testing strategies). This approach is proposed in $\mathrm{REACH}$, and we suggest that it should also be used to improve PBT assessment under the other frameworks in cases where it could deliver valuable additional information.

\section{Discussion}

\section{Persistence, bioaccumulation and toxicity criteria}

In this chapter, we introduce the three criteria, i.e. persistence (P), bioaccumulation (B) and toxicity $(\mathrm{T})$. The general scheme is to test sequentially for $\mathrm{P}$, then $\mathrm{B}$ and lastly for $\mathrm{T}$, as only substances with high persistence must be considered further for PBT identification. This sequence is further justified by the need to limit testing for animal welfare reasons.

A substance is considered a PBT or $\mathrm{vPvB}$ substance if it fulfills the $\mathrm{P}, \mathrm{B}$ and $\mathrm{T}$ or the $\mathrm{vP}$ and $\mathrm{vB}$ criteria. In the following sections, for each PBT criterion, the criteria for the 'definitive assessment' are presented first. This is followed by the criteria for the 'screening assessment', which is carried out in cases of limited data availability.

\section{Persistence}

The persistence of a substance in soil, water or sediment is controlled by its intrinsic properties and also influenced by environmental conditions (e.g. temperature, presence of degraders, $\mathrm{pH}$, moisture content in case of soil, bioavailability of the substance). The assessment of persistence is influenced by the type and quality of available studies and also by the interpretation of the available data.

Persistence is not characterised consistently in the different frameworks, but, as suggested by Boethling et al. [15] and in [9], it is the degradation half-life $\left(\operatorname{DegT}_{50}\right)$ which should be compared to the trigger values in the various compartments, as a mere transfer (dissipation) from one compartment to the other does not affect the persistence of a substance. DegT $_{50}$ values are commonly estimated from the parent substance in extractable residues in degradation simulation studies performed according to e.g. OECD test guidelines 307, 308 or 309 [16-18].

In the context of PBT identification, $\mathrm{DT}_{50}$ should not refer to dissipation half-lives (Diss $\mathrm{T}_{50}$ ) as these refer to cases where the substance may not be degraded but only redistributed (e.g. from the water phase to sediment or the atmosphere, or leaching, run-off, volatilisation or uptake into plants). This is explicitly mentioned in the revised Annex XIII of the REACH regulation [7], while the PPP Regulation [2] only refers to half-lives in general.
Definitive assessment. If degradation simulation tests have been conducted to meet legal requirements, a sufficient amount of reliable data is usually available to complete a definitive assessment by comparing the Deg $\mathrm{T}_{50}$ values directly to the criteria as reported in Table 1 . However, a number of issues related to these values should be addressed.

Type of kinetics for deriving $\operatorname{Deg}_{50}$. We suggest using single first-order (SFO) kinetics to derive Deg $\mathrm{T}_{50}$ values for the purpose of comparing them to the trigger values. Best fit kinetics such as first-order multicompartment (FOMC) can be used if they are recalculated by dividing the $\operatorname{DegT}_{90}$ values by a factor of 3.32 or by using the degradation rate constant of the slower phase in case of double first-order in parallel model (DFOP) or Hockey stick (HS) kinetics. This proposal is based on the Guidance Document on Estimating Persistence and Degradation Kinetics from Environmental Fate Studies on Pesticides in EU Registration [19]. This document gives detailed guidance on the derivation of $\mathrm{DegT}_{50}$ values, which is used for risk assessment of biocides, medicinal products and PPPs and could be applied to other substance groups as well.

\section{Normalisation of the $\operatorname{Deg}_{50}$ to specific conditions.} Variable conditions such as temperature, humidity, microbial populations and others have a large influence on the rate of degradation of a chemical substance. Simulation studies in the laboratory are conducted at various temperatures: OECD test guidelines 307 and 308 on transformation in soil and in water-sediment systems $[16,17]$ recommend testing at $20^{\circ} \mathrm{C}$ and $10^{\circ} \mathrm{C}$ (if the substance is used in colder climates), the US EPA recommends $22^{\circ} \mathrm{C}$ for soil testing [20] and for many pesticides, tests have been performed both at $20^{\circ} \mathrm{C}$ and $10^{\circ} \mathrm{C}$. For the purpose of comparing different data, half-lives should thus be normalised to a defined temperature since it is a criterion which strongly influences the outcome of a degradation test and, furthermore, is quantifiable unlike other related criteria such as differences in microorganism populations. For PBT identification, normalisation of DegT $\mathrm{T}_{50}$ values to a temperature of $12^{\circ} \mathrm{C}$ has been applied to many biocides and other chemicals, as prescribed in the TGD [21], and is included as an option in the REACH guidance on information requirements and chemical safety assessment (Chapter R.7b [8]). This temperature of $12^{\circ} \mathrm{C}$ is also included in the draft 'Guidance on the assessment of persistent, bioaccumulative and toxic (PBT) or very persistent and very bioaccumulative (vPvB) substances in veterinary medicine' [22]. By contrast, DegT $_{50}$ values for PPPs are normalised to $20^{\circ} \mathrm{C}$, both for laboratory and field data for risk assessment; this temperature has also been proposed for PBT identification [11]. For 
a consistent approach between frameworks, we propose normalising the $\operatorname{DegT}_{50}$ values to $12^{\circ} \mathrm{C}$ because this temperature is established or suggested under the majority of frameworks (i.e. Biocides Regulation, REACH and medicinal products Directives).

Degradation in soil: inclusion of field studies. Laboratory simulation studies can provide information on both route and rate of degradation. This permits the estimation of primary degradation rates $\left(\mathrm{DegT}_{50}\right)$, as well as the measurement of carbon dioxide evolution and of formation of metabolites and bound residues. But the small size of the test systems is a limiting factor for both the test duration and the diversity of the microbial population (which may limit the probability of having competent degraders and which usually also decreases over time).

For PPPs, terrestrial field (dissipation) studies under realistic outdoor conditions are required when the $\operatorname{Deg}_{50}$ exceeds 60 days at $20^{\circ} \mathrm{C}$ in laboratory studies [2]. Such field studies allow $\mathrm{DT}_{50}$ values to be derived under conditions going beyond the limitations of laboratory tests. A number of conditions may be more realistic compared to laboratory studies (e.g., prolonged duration, fluctuating temperature and humidity, higher biological activity, larger test system), but may not be as easy to compare or reproduce. A limiting aspect in such testing is that a dissipation half-life, and not a degradation half-life, will be derived. The measured residues result from biotic degradation but also from photolytic transformation and field dissipation processes like volatilisation, leaching and runoff. However, a novel approach to estimate a $\operatorname{DegT}_{50}$ in field studies has recently been proposed by EFSA [23] in which dissipation processes on the soil surface are estimated separately from biodegradation in the soil compartment. This Deg $\mathrm{T}_{50}$ has to be normalised for temperature and humidity for comparability reasons. Although this guidance was developed for the evaluation of persistence of PPPs in field studies, in principle, its rationale and approach should also be applicable to other types of substances. Thus, we suggest including field studies in persistence assessment as additional data, provided that it is possible to derive DegT $T_{50}$ values. This is in line with the WoE approach, which considers all available information in the decision process.

Evaluation of $\operatorname{DegT}_{50}$ values for the water and sediment compartments. There is no standardised test that measures true degradation only in the sediment compartment. The test on 'aerobic and anaerobic transformation in aquatic sediment systems' (OECD test guideline 308 [17]) is generally used to assess the fate of compounds in water and sediment systems, but reliable separate $\mathrm{DegT}_{50}$ values for water and for sediment cannot usually be derived from the study results. Therefore, separate
$\operatorname{DegT}_{50}$ values are generally not available for comparison with the trigger values.

Available $\mathrm{DT}_{50}$ values for the water phase in many cases only refer to dissipation, as many substances, especially those with high $\log K_{\mathrm{OC}}$ and low water solubility, are quickly transferred to the sediment. The Aerobic Mineralisation in Surface Water - Simulation Biodegradation Test (OECD 309 [18]) is available to measure degradation in the water phase, but to date it has rarely been used for the assessment of environmental fate.

We suggest comparing the Deg $\mathrm{T}_{50}$ of the total system to the two trigger values for water and sediment. More specifically, in the case of a substance that is rapidly transferred into the sediment, the $\operatorname{DegT}_{50}$ of the total system should be compared with the trigger value for sediment (120 and 180 days for persistence assessment). For substances that mostly remain in the water phase, the DegT $_{50}$ values should be compared with the trigger values for water (40 and 60 days for persistence assessment). There will be many cases where a substance can be found in both the water and sediment phases, which means that clear criteria are necessary to judge which of the trigger values is appropriate.

\section{Selection of an adequate $\operatorname{Deg}_{\mathbf{5 0}}$ from multiple studies.} As explained above, testing requirements for persistence differ greatly between regulatory frameworks. The information is summarized in Table 2 .

If several valid degradation studies for one compartment are available, their quality and reliability are an important consideration. We propose the following approach to processing the information gathered:

- When a small number of studies is available (i.e. up to $4 \mathrm{DegT}_{50}$ values), we suggest selecting the worst-case $\mathrm{DegT}_{50}$ rather than performing a weak statistical evaluation.

- When more studies are available (i.e. 5 and more DegT $_{50}$ values), various approaches are possible: The most conservative approach would be to use the worst-case DegT $_{50}$; A less conservative approach is the geometric mean, which gives a medium degradation rate, but does not provide information on the range of variability of the values and may produce some false negatives, i.e. fail to recognise some persistent substances;

An intermediate approach is the 90th percentile which may produce some false positives.

- In cases where the studies are not equally reliable, the range and distribution of all available Deg $\mathrm{T}_{50}$ values should be examined in the WoE approach. This is done by assigning different weights to them according to the quality of the studies, in order to 
select an acceptable value (or range of values) to represent the persistence of the substance.

If five or more $\operatorname{Deg} T_{50}$ values are available, we suggest selecting the geometric mean. This is to be considered together with the decision to normalise the $\operatorname{Deg} \mathrm{T}_{50}$ values to a temperature of $12^{\circ} \mathrm{C}$, in order to achieve an overall reasonable conservatism (i.e. target the problematic substances).

This choice is illustrated by the evaluation of a number of substances (64) with 5 and more soil laboratory $\operatorname{DegT}_{50}$ values available, whose the degradation data have been recently assessed as part of the regular national PPP registration process in Germany. This exercise indicates how many substances would be identified as $\mathrm{P}$, on the basis of the above evaluation parameters.

- For degradation in soil, only data from laboratory studies was used. Field studies were excluded since no evaluations according to the new EFSA scientific opinion [23] were available yet.

- For water-sediment studies, the total system DegT $T_{50}$ was used and compared to the sediment value of 120 days.

- Temperature was normalised both to $12^{\circ} \mathrm{C}$ and $20^{\circ} \mathrm{C}$;

- The maximum DegT 50 value (worst-case scenario) and the geometric mean of all $\operatorname{DegT}_{50}$ were used.

The results indicate that the percentage of substances fulfilling the P criterion varies from about 39\% for the least conservative approach $\left(20^{\circ} \mathrm{C}\right.$ and geometric mean) to $73 \%$ for the most conservative approach $\left(12^{\circ} \mathrm{C}\right.$ and maximum $\operatorname{DegT}_{50}$ ) and is intermediate (i.e. about $53 \%$ ) when the geometric mean and a temperature of $12^{\circ} \mathrm{C}$ are used (Table 3).

\section{Screening assessment}

For many chemicals, especially those registered under $\mathrm{REACH}$, only a limited data set is available, as explained in Chapter 2. In this case, the assessment of persistence has to be based on screening data. If no further data are presented, the result of the screening assessment (i.e. screening P) should be used for further regulatory action unless refuted by more definitive data such as valid simulation test data.

In the screening approach, the evaluation of persistence is mainly based on tests on ready biodegradability (OECD 301 A-F [24] and OECD 310 [25]).

Substances which are readily degradable are considered not to be persistent (not P) [26], as the test is fairly stringent. Due to the high rate of mineralisation, an accumulation or formation of relevant metabolites is improbable. On the other hand, substances that are not readily biodegradable are considered to be potentially persistent (potentially P, sometimes also called 'screening P'), until further data are presented. Due to the stringency of the test, this results in a high number of false positives; thus, 'enhanced ready biodegradability' tests (based on ready biodegradability tests but with prolonged test duration, higher concentration of microbial biomass, increased test volumes, but no pre-adaptation) may be used for chemicals registered under REACH to prove their degradability without having to conduct more expensive and timeconsuming simulation studies.

Other available data on persistence also have to be examined. This may include data on abiotic degradation, monitoring data, QSAR estimations and read across from structurally related substances.

\section{Main outcomes and open points}

Our proposal is to base P identification on degradation, and not on dissipation, as recommended previously $[6,17]$. Thus, trigger values should be compared to DegT $\mathrm{T}_{50}$ values. The final identification of substances as persistent should be based on a reasonable conservatism for the various regulatory frameworks and not on a combination of various worst-case choices. Our proposal is summarised in Table 4.

It should be noted that in the $\mathrm{P}$ assessment, other information generated in degradation simulation studies such as the formation of non-extractable residues (NER) or the mineralisation rate are not formally considered. Such information can only be taken into account in a

Table 3 Estimation of percentages of substances fulfilling P criterion

\begin{tabular}{|c|c|c|c|c|c|}
\hline Parameter & & Persistent in both soil and w/s system & Persistent in soil only & Persistent in w/s system only & Total \\
\hline \multirow[t]{4}{*}{ Maximum } & $12^{\circ} \mathrm{C}$ & $45 \%$ & $17 \%$ & $11 \%$ & $73 \%$ \\
\hline & & $(29$ of 64$)$ & (11 of 64$)$ & (7 of 64$)$ & (47 of 64$)$ \\
\hline & $20^{\circ} \mathrm{C}$ & $34 \%$ & $8 \%$ & $13 \%$ & $55 \%$ \\
\hline & & $(22$ of 64$)$ & $(5$ of 64$)$ & $(8$ of 64$)$ & (35 of 64$)$ \\
\hline \multirow[t]{4}{*}{ Geo mean } & $12^{\circ} \mathrm{C}$ & $30 \%$ & $3 \%$ & $20 \%$ & $53 \%$ \\
\hline & & $(19$ of 64$)$ & (2 of 64$)$ & $(13$ of 64$)$ & (34 of 64$)$ \\
\hline & $20^{\circ} \mathrm{C}$ & $14 \%$ & $3 \%$ & $22 \%$ & $39 \%$ \\
\hline & & (9 of 64$)$ & $(2$ of 64$)$ & (14 of 64$)$ & (25 of 64$)$ \\
\hline
\end{tabular}

This evaluation was performed with a dataset of 64 PPP. 
Table 4 Main elements of our proposal for a harmonized assessment of persistence across regulatory frameworks

\begin{tabular}{|c|c|c|}
\hline & \multicolumn{2}{|l|}{ Persistence } \\
\hline & Definitive assessment & Screening assessment \\
\hline \multirow[t]{9}{*}{ Criteria } & Half-life & Ready biodegradability \\
\hline & Water: & \multirow{8}{*}{$\begin{array}{l}\text { Enhanced ready } \\
\text { biodegradability }\end{array}$} \\
\hline & $\begin{array}{l}>60 \text { days in marine } \\
\text { (>60 days) }\end{array}$ & \\
\hline & $\begin{array}{l}>40 \text { days in fresh- or } \\
\text { estuarine (>60 days) }\end{array}$ & \\
\hline & Sediment: & \\
\hline & $\begin{array}{l}>180 \text { days in marine } \\
\text { (>180 days) }\end{array}$ & \\
\hline & $\begin{array}{l}>120 \text { days in fresh- or } \\
\text { estuarine (>180 days) }\end{array}$ & \\
\hline & Soil: & \\
\hline & $>120$ days (>180 days) & \\
\hline \multirow[t]{10}{*}{ Proposal } & $\begin{array}{l}\text { Considering } \operatorname{Deg}_{50} \text { and not } \\
\text { DissT }_{50}\end{array}$ & $\begin{array}{l}\text { Other information to } \\
\text { consider }\end{array}$ \\
\hline & Normalising DegT $_{50}$ to $12^{\circ} \mathrm{C}$ & Abiotic degradation \\
\hline & $\begin{array}{l}\text { Inclusion of field studies if } \\
\text { DegT }_{50} \text { can be derived }\end{array}$ & Monitoring data \\
\hline & $\begin{array}{l}\text { Selecting } \operatorname{Deg}_{50} \text { from } \\
\text { multiple studies: }\end{array}$ & QSAR \\
\hline & For $\leq 4$ values: worst case & \multirow{6}{*}{$\begin{array}{l}\text { Read-across from } \\
\text { structurally related } \\
\text { substances }\end{array}$} \\
\hline & $\begin{array}{l}\text { For } \geq 5 \text { values: geometric } \\
\text { mean, or WoE }\end{array}$ & \\
\hline & $\begin{array}{l}\text { Water and sediment } \\
\text { systems: comparing DegT } T_{50} \\
\text { to trigger }\end{array}$ & \\
\hline & $\begin{array}{l}\text { Values of water and } \\
\text { sediment; need clear } \\
\text { criteria }\end{array}$ & \\
\hline & Other information to consider & \\
\hline & $\begin{array}{l}\text { Formation of NER or } \\
\text { mineralisation rate }\end{array}$ & \\
\hline
\end{tabular}

The $\mathrm{P}$ and $\mathrm{vP}$ criteria are included for definitive and screening assessments.

WoE approach but should not be ignored. Where NER are the result of degradation and incorporation into the microbial biomass, their formation can be considered as a detoxification step. On the other hand, where the original substance may be remobilised, NER formation should be interpreted as a specific form of compound persistency. The issue of NER is currently being examined in various contexts [27-29].

\section{Bioaccumulation}

Substances with a high potential for bioaccumulation are of special concern even if introduced into the environment in low concentrations. They are taken up by biota and their concentrations in the tissues result from the combination of uptake and depuration. Uptake occurs either via the surrounding medium - water or soil - (bioconcentration), food (dietary bioaccumulation) or the food chain (biomagnification). These processes are driven by the properties of the substance (mostly hydrophobicity as determined by octanol/water or octanol/air partition coefficient, i.e. $K_{\mathrm{OW}}$ or $K_{\mathrm{oa}}$, as well as other characteristics, e.g. protein-binding properties) but they also depend on the environmental matrices (i.e. aquatic, terrestrial) and on the biological, ecological and trophic characteristics of the organisms.

The bioconcentration factor $(\mathrm{BCF})$ is the usual basis for defining the B criterion in PBT assessment although it is not always the most relevant indicator of the environmental bioaccumulation potential of a substance, as stated in [30]. Indeed other available data (e.g. monitoring data, biomagnification, bioaccumulation in other species, literature data) should also be taken into account [30-32]. We propose therefore that all available relevant information on bioaccumulation should be considered in a WoE approach.

Definitive assessment. The definitive assessment of the bioaccumulation potential is based on the bioconcentration factor $(\mathrm{BCF})$ in an aquatic species. The trigger value for the $\mathrm{BCF}$ is set at $>2,000 \mathrm{~L} / \mathrm{kg}$ for $\mathrm{B}$ assessment and at $>5,000 \mathrm{~L} / \mathrm{kg}$ for $v B$ assessment.

Bioconcentration. The bioconcentration factor $(\mathrm{BCF})$ is defined as the ratio of concentration in fish to the concentration in the surrounding medium. It is generally derived experimentally according to OECD Test Guideline 305 I (bioconcentration flow-through fish test [33]). This test is appropriate for substances with moderate hydrophobicity, so it is necessary to determine the concentration of the test substance in the exposure medium and in fish. The test is mandatory for risk assessment for PPPs, biocides and human medicinal products if $\log K_{\mathrm{OW}}$ exceeds 3 , and for veterinary pharmaceuticals if $\log K_{\mathrm{Ow}}$ exceeds 4. It is also required for REACH substances with a production volume above $100 \mathrm{t} / \mathrm{a}$ and a $\log K_{\mathrm{OW}}>3$.

The BCF should be normalised to a lipid content of $5 \%$ of total body weight (average lipid content of fish commonly used in $[33,34])$. Potential growth dilution should also be taken into account $[26,33]$, as well as indications of slow or poor depuration.

Bioaccumulation and biomagnification. Bioaccumulation and biomagnification should also be taken into account for species such as fish since the relevant route of exposure may be the food, especially for substances with high $\log K_{\mathrm{OW}}$ and for substances poorly soluble or nonsoluble in water. Indeed for such substances, it may be technically difficult or not feasible (i) to conduct a bioconcentration fish test since aqueous exposure via gill 
uptake is reduced and no longer accounts for the dominant exposure pathway, and/or (ii) to analyse the concentration in water. Instead, a dietary fish test has been developed to determine uptake by ingestion, yielding a biomagnification factor (BMF) [33].

A BMF $>1$ is a supportive indication of high bioaccumulation and the $\mathrm{B}$ criterion is thus considered as fulfilled. Nevertheless, a definitive trigger value for BMF has not yet been established. Hence, a bioaccumulation potential cannot be excluded in cases of $\mathrm{BMF}<1$. Recalculation of the dietary study data into aquatic BCF values has been suggested [26] but these methods have to be checked carefully for their domain of applicability [35].

Supplementary information. Other reliable data should also be considered, when available:

- High bioaccumulation in organisms other than fish, as mentioned in the Stockholm Convention [36] and the revised Annex XIII criteria in REACH [7]; e.g. bioaccumulation in mussels [37] or oligochaetes [38]. In some cases, lipid normalisation concentrations should be revised since a normalisation to a lipid content of $5 \%$ of the body weight - as proposed for fish (see above) - may not be suitable for species with low lipid content (e.g. mussels);

- Indicators other than BCF calculated from environmental data (i.e. measured in mesocosms or in the field), assessing the accumulation of substances from water and diet such as the bioaccumulation factor (BAF), their specific accumulation in food webs expressed as biomagnification factor (BMF) or trophic magnification factor (TMF);

- Bioaccumulation via different uptake routes, e.g. terrestric or benthic oligochaetes [38,39]. As bioaccumulation may differ between water- and air-breathing organisms, aquatic bioaccumulation data should not be transfered to air-breathing organisms [31];

- Accumulation in specific tissues, e.g. substances such as PCBs accumulate extensively in fatty tissues and organs from wildlife samples [40]. In some cases, inefficient or nonexistent detoxification processes may be responsible for high BCF values (e.g. TBT in molluscs) $[41,42]$.

- Non-lipid-based accumulation for substances such as perfluorinated acids, which bioaccumulate in blood plasma proteins $[43,44]$. Perfluorooctane sulfonate (PFOS) can be considered as bioaccumulative even though the BCF is below the trigger value $(<2,000)$ but it has a long half-life, high toxicity and high biomagnification.
- Toxicokinetic and chronic studies with mammals as well as in vitro data on aquatic bioaccumulation as required for human toxicological assessment are also available.

Screening assessment. The screening criterion for assessing bioaccumulative properties is derived from the hydrophobicity of the compound. A substance is considered to potentially fulfil the $\mathrm{B}$ criterion when $\log K_{\mathrm{OW}}$ exceeds a value of 4.5 [21].

Suitable quantitative structure-activity relationship (QSAR) models for estimating the BCF could be used if $\log K_{\mathrm{OW}}$ is between 4.5 and 6 , as the available BCF QSAR models are linear between $\log K_{\mathrm{OW}} 2$ to $6[21,45]$. For highly hydrophobic substances $\left(\log K_{\mathrm{OW}}>6\right)$, the potential for bioaccumulation must be assessed through expert judgement and on a case-by-case basis, taking into account the specific physico-chemical properties of the substance (e.g. molecular size and weight, log $K_{\text {Ow }}$ ) and the available BCF QSAR models (e.g. parabolic equation in $[21,46])$.

Since hydrophobicity does not drive all bioaccumulation processes, other information has to be considered, e.g. surface activity, structural alerts, high $\log K_{\mathrm{OA}}$ (octanol/air partition coefficient) as an indicator of a possible bioaccumulation in air-breathing organisms or read-across approaches from structurally related substances.

Main outcomes and open points. Our proposal (see Table 5) is to consider all available endpoints in addition to the BCF for aquatic organisms in the WoE approach, as there are other standardised tests resulting in the derivation of other BAFs (e.g. benthic oligochaetes [38]; terrestric oligochaetes [39]) and BMFs (fish dietary test guideline [33]). Currently, a comparison between the results of these tests (e.g. BMF, BAF) and a BCF is difficult to make for several reasons such as different uptake mechanisms of different taxa. Also, in vitro tests for bioaccumulation (e.g. [47]) are being developed and using information from field studies and TMF (e.g. [42,48]) is being considered. Taking into account these various aspects will improve the assessment of bioaccumulation.

\section{Toxicity}

For substances with high persistence and bioaccumulation potential, i.e. fulfilling the $\mathrm{P}$ and the $\mathrm{B}$ criteria, longterm exposure of organisms can be expected, which may cover the whole life-span of the exposed organisms and even several generations. Therefore, long-term and/or chronic ecotoxicity data, ideally covering the reproductive stages, should be used for assessing the $\mathrm{T}$ criterion in the context of a PBT assessment. 
Table 5 Main elements of our proposal for a harmonized assessment of bioaccumulation across the regulatory frameworks

\begin{tabular}{|c|c|c|}
\hline & \multicolumn{2}{|l|}{ Bioaccumulation } \\
\hline & Definitive assessment & Screening assessment \\
\hline Criteria & $\mathrm{BCF}>2,000 \mathrm{~L} / \mathrm{kg}(>5,000 \mathrm{~L} / \mathrm{kg})$ & Log $K_{\text {ow }}>4.5$ \\
\hline \multirow[t]{9}{*}{ Proposal } & BCF (normalised to $5 \%$ lipid content) & $\begin{array}{l}\text { QSAR if log } K_{\text {ow }} \text { is between } 4.5 \text { and } 6, \log K_{\text {ow }}>6 \text { : expert judgement, } \\
\text { case- by-case }\end{array}$ \\
\hline & $\begin{array}{l}\text { For high log } K_{\mathrm{ow}} \text { and poorly soluble or non-soluble: } \\
\text { consider BAF, BMF (BMF > } 1 \text { indicative) }\end{array}$ & Other information to consider \\
\hline & Other information to consider & Surface-activity \\
\hline & High bioaccumulation in species other than fish & Structural alerts \\
\hline & Different uptake routes & High log $K_{\mathrm{OA}}$ for air-breathing organisms \\
\hline & Accumulation in specific tissues & Read-across from structurally related substances. \\
\hline & Non-lipid based accumulation & \\
\hline & Toxicokinetic and chronic studies with mammals & \\
\hline & In vitro data on aquatic bioaccumulation & \\
\hline
\end{tabular}

The $B$ and $v B$ criteria are included for definitive and screening assessments.

Definitive assessment The substance fulfils the T criterion in any of the following situations:

1. Long-term or chronic NOEC or $\mathrm{EC}_{10}$ values from ecotoxicological tests with aquatic organisms are below the trigger of $0.01 \mathrm{mg} / \mathrm{L}$, or

2. It is classified as carcinogenic, categories 1 and 2 [49] or $1 \mathrm{~A}$ and $1 \mathrm{~B}$ [50], mutagenic, categories 1 and 2 [49] or $1 \mathrm{~A}$ and $1 \mathrm{~B}$ [50] or toxic for reproduction, categories 1, 2 and 3 [49] or $1 \mathrm{~A}, 1 \mathrm{~B}$ and 2 [50], so-called CMR substances, or

3. There is other evidence of chronic toxicity, as identified by the classification of the substance as $\mathrm{T}$, R45, R46, R48, R60 and R61 or Xn, R48, R62, R63, R64 [49], or specific target organ toxicity and repeated exposure (STOT RE category 1 or 2) [50].

If any classification criteria under 2 or 3 are met, there is no need to perform any further aquatic studies for evaluation of toxicity.

Supplementary information. When substances such as PPPs and biocides (i.e. produced to control pests) are tested for toxic effects, it is likely that these will occur both in the target species and in non-target species belonging to the same taxonomic group. Testing for the $\mathrm{T}$ criterion refers only to aquatic organisms. However, effects on non-aquatic species could be relevant as well, bearing in mind, however, that the use of vertebrates for testing should generally be minimised.

In this context, we recommend that other reliable data should also be considered where available:

- For PPPs and biocides, results of subchronic, chronic or reproduction studies with birds and mammals may be available. In this context, a NOEC of $\leq 30 \mathrm{mg} / \mathrm{kg}$ food in a long-term bird study should be considered as an indication that the $\mathrm{T}$ criterion is met $[21,26]$.

- It could be relevant to use toxicity data from longterm ecotoxicological tests on terrestrial organisms, e.g. OECD TG 222 [51]. However, in such a case, it has to be clarified whether such an assessment should (i) be based on trigger values comparable to those used in the assessment of toxicity for aquatic organisms (e.g. $<0.01 \mathrm{mg} / \mathrm{kg}$ dry soil), and (ii) take into account differences in the exposure of the respective organisms.

- For substances with high $\log K_{\mathrm{ow}}$, tests performed with sediment-dwelling species may provide better information than tests with pelagic species. Indeed, the results may be more reliable if the substance partitions out of solution. Also, the information gathered may be more useful if it is focused on the compartment in which the substance will likely be found. A way to determine whether a substance has equivalent toxicity in sediment as in the water column should be proposed.

Furthermore, information on aquatic toxicity other than that gathered from standard studies and provided for in relevant test guidelines, i.e. information from nonstandard studies and non-standard endpoints, could be used as supporting data. Also, the endocrine disrupting potential of chemical substances is an issue. It is planned to develop a general concept for EDCs which should be consistent and should ensure that endocrine disruptors are dealt with in a consistent and coordinated manner across the different regulatory frameworks [52]. This issue has been discussed by a panel of experts of the German 
Federal Environment Agency (UBA) [53]. This could be considered for inclusion of EDC potential in the harmonised assessment of the $\mathrm{T}$ criterion.

Screening assessment. The screening criteria for assessing toxicity are based on short-term (acute) toxicity of the compound on aquatic organisms. They are as follows:

- A substance with at least one acute $\mathrm{LC}_{50} / \mathrm{EC}_{50}$ value below $0.1 \mathrm{mg} / \mathrm{L}$ is considered to be potentially toxic (potentially $\mathrm{T}$, sometimes called 'screening T' under $\mathrm{REACH}$ ). This classification can only be revoked by adequate chronic data, i.e. for determination of definitive criteria for $\mathrm{T}$ [26];

- A substance with acute $\mathrm{LC}_{50} / \mathrm{EC}_{50}$ values below 0.01 $\mathrm{mg} / \mathrm{L}$ is considered to be toxic $(\mathrm{T})$, as NOEC or $\mathrm{EC}_{10}$ values from prolonged or chronic toxicity studies will always be below acute $\mathrm{LC}_{50}$ or $\mathrm{EC}_{50}$ values for the same taxon [26].

Other possibilities include the use of QSAR and readacross from structurally related substances, if testing of the substance is technically impossible because of its physicochemical properties or in cases of data poor situations.

Main outcomes The criteria for the definitive and the screening assessment of the $\mathrm{T}$ criterion are to a large extent consistent between the different regulatory frameworks. However, in situations where data availability or adequacy is too poor to support a definitive or a screening assessment, we propose that other indications of toxicity potential should be taken into account (Table 6). These include, for example, endpoints from toxicity tests with terrestrial organisms, endocrine-disrupting properties, QSAR calculations or harmonised toxicological classifications. Since trigger values have not yet been set for these endpoints, a WoE approach is needed to decide on a case-by-case basis whether a substance fulfils the T criterion as part of PBT assessment.

\section{Considering metabolites and transformation products}

Transformation products can be as or even more persistent than their parent compounds and thus must be included in chemical assessment. However, the regulatory frameworks for substances differ with respect to the inclusion of metabolites or transformation products in PBT identification. For PPPs, the consideration of metabolites in the context of PBT identification has been controversially discussed, as PPPs Regulation 1107/2009 [2] does not address this issue precisely and only refers to the relevance of metabolites in a general sense (Art. 3 (32) Annex II point 3.3). However, a current proposal envisages excluding metabolites in the process of PBT identification and in the identification of candidates for
Table 6 Main elements of our proposal for a harmonized assessment of toxicity across regulatory frameworks

\begin{tabular}{|c|c|c|}
\hline & \multicolumn{2}{|l|}{ Toxicity } \\
\hline & Definitive assessment & Screening assessment \\
\hline \multirow[t]{3}{*}{ Criteria } & $\begin{array}{l}\text { NOEC (long-term) }<0.01 \mathrm{mg} / \mathrm{L} \\
\text { marine or freshwater species }\end{array}$ & $\begin{array}{l}\geq 1 \text { value for acute } \\
\mathrm{LC}_{50} / \mathrm{EC}_{50}<0.1 \mathrm{mg} / \mathrm{L} \text { : } \\
\text { potentially toxic }\end{array}$ \\
\hline & CMR substances & \multirow{2}{*}{$\begin{array}{l}\text { Acute } \mathrm{LC} C_{50} / \mathrm{EC}_{50} \\
\text { values }<0.01 \mathrm{mg} / \mathrm{L} \text { : toxic }\end{array}$} \\
\hline & $\begin{array}{l}\text { Other evidence of chronic } \\
\text { toxicity }\end{array}$ & \\
\hline \multirow[t]{6}{*}{ Proposal } & Other information to consider & $\begin{array}{l}\text { Other information to } \\
\text { consider }\end{array}$ \\
\hline & $\begin{array}{l}\mathrm{NOEC} \leq 30 \mathrm{mg} / \mathrm{kg} \text { food, } \\
\text { birds and mammals }\end{array}$ & QSAR \\
\hline & $\begin{array}{l}\text { Long-term tests on terrestrial } \\
\text { organisms }\end{array}$ & \multirow{4}{*}{$\begin{array}{l}\text { Read-across from } \\
\text { structurally related } \\
\text { substances. }\end{array}$} \\
\hline & $\begin{array}{l}\text { High log Kow: sediment- } \\
\text { dwelling species tests }\end{array}$ & \\
\hline & $\begin{array}{l}\text { Information from non- } \\
\text { standard aquatic studies } \\
\text { and endpoints }\end{array}$ & \\
\hline & $\begin{array}{l}\text { Endocrine-disrupting } \\
\text { potential }\end{array}$ & \\
\hline
\end{tabular}

The T criteria for definitive and screening assessments is included.

substitution (i.e. substances that meet two of the three criteria) [11]. REACH requires that registration documents for chemicals produced or imported in excess of $100 \mathrm{t} / \mathrm{a}$ include information about metabolites and transformation products [54]. They are to be considered in PBT identification if they exceed $0.1 \%$ of the substance weight $[9,26]$. For both human and veterinary medicinal products, transformation products $>10 \%$ are considered to be 'relevant' and thus included in risk assessment as well as in PBT assessment. In the assessment of biocides, major metabolites $(\geq 10 \%$ or $\geq 5 \%$ at two consecutive sampling points or maximum not reached but $\geq 5 \%$ of the active substance at the final time point) are considered in PBT identification and minor metabolites only if data are available or there is any reason for concern. It is questionable whether relevance can be defined in terms of any percentage. Since humans and the environment should be protected from exposure to PBT and vPvB substances, the same criteria should apply to metabolites or transformation products as to the parent compounds. We suggest that in all regulatory frameworks, metabolites and transformation products should be included in the assessment.

\section{Conclusions}

The various European regulatory frameworks on chemical substances agree that exposure of humans and the environment to substances identified as PBT or vPvB must be avoided. But the decision-making process is not straightforward and harmonisation between the frameworks is a 
real challenge. Indeed, despite the same trigger values, the identification of a PBT or $\mathrm{vPvB}$ substance will depend on how the criteria are used in the various frameworks to determine.

(i) For persistence, the half-lives in terms of e.g. temperature normalisation, how field studies are considered, appropriate statistics, and others,

(ii) For bioaccumulation, e.g. the endpoints - in addition to the BCF for aquatic organisms considered in a WoE approach, and

(iii) For toxicity, e.g. indications of toxicity potential considered when availability or adequacy of data is too poor to support a definitive or a screening assessment.

Differences in testing requirements, data availability, data evaluation and interpretation were screened and discussed to identify the best methods. The current proposal is thus characterised by its robustness against those differences and by its reasonable conservatism.

For example, the proposal for the Persistence criterion is based on the outcome of an evaluation performed on a set of selected active substances of PPPs. We recommend (i) normalising the $\operatorname{DegT}_{50}$ values to a temperature of $12^{\circ} \mathrm{C}$ as this is established in biocides legislation and suggested in other regulations (REACH and medicinal products directives), and (ii) selecting the geometric mean if five or more $\operatorname{DegT}_{50}$ values are available, or a suitable value or range of $\mathrm{Deg}_{50}$ values in a $\mathrm{WoE}$ approach if the studies are not equally reliable.

Finally, the differing mandatory measures imposed by the various regulations should be considered together with the present proposal on harmonised $\mathrm{PBT} / \mathrm{vPvB}$ identification in order to ensure that the truly problematic substances are identified.

\section{Abbreviations}

B: Bioaccumulation; BAF: bioaccumulation factor; BCF: bioconcentration factor; BMF: biomagnification factor; CMR: carcinogenic, mutagenic and toxic for reproduction; Deg $_{50}$ : degradation half-life; Diss $_{50}$ : dissipation half-life; $\mathrm{EC}_{10}$ : effect concentration, $10 \%$; $\mathrm{EC}_{50}$ : effect concentration, 50\%; EDCs: endocrine-disrupting chemicals; EFSA: European Food Safety Agency; EU: European Union; FOMC: first-order multi-compartment; Kow: octanol/ water partition coefficient; $K_{\mathrm{o}}$ : octanol/air partition coefficient; $L_{5} C_{50}$ : lethal concentration, 50\%; NER: non-extractable residues; NOEC: no observed effect concentration; OECD: Organisation for Economic Cooperation and Development; P: persistence; PBT: persistent, bioaccumulative and toxic; PCBs: polychlorinated biphenyls; PFOS: perfluorooctane sulfonate; PPPs: plant protection products; QSAR: quantitative structure-activity relationships; REACH: Registration, Evaluation, Authorisation and Restriction of Chemicals; SETAC: Society for Environmental Toxicology and Chemistry; SFO: single first order; STOT RE: specific target organ toxicity - repeated exposure; SVHC: substances of very high concern; T: toxicity; t/a: tons per year; TBT: tributyltin hydride; TG: test guideline; TGD: Technical Guidance Document; TMF: trophic magnification factor; UBA: Umweltbundesamt (German Federal Environment Agency); US EPA: United States Environmental Protection Agency; $\vee \mathrm{PvB}$ : very persistent and very bioaccumulative; WoE: weight of evidence.

\section{Competing interests}

The authors declare that they have no competing interests.

\section{Authors' contributions}

$C R, A F, G H, U J, A K, M N, I P, J S, A W, K W, J W$ and SD contributed to the collection of assessment procedures in PBT assessment for the respective frameworks, and drafted the first manuscript. SD and CR edited the manuscript to include all comments and finalised the manuscript. All authors read and approved the final manuscript.

\section{Acknowledgements}

We thank our colleagues from the Federal Environment Agency (Umweltbundesamt, UBA, Germany) and other authorities as well as colleagues from academia and industries for fruitful discussions.

\section{Author details}

${ }^{1}$ Section International Chemicals Management, Federal Environment Agency (UBA), Wörlitzer Platz 1, 06844 Dessau-Roßlau, Germany. ${ }^{2}$ Section Biocides, Federal Environment Agency (UBA), Wörlitzer Platz 1, 06844 Dessau-Roßlau, Germany. ${ }^{3}$ Section Plant Protection Products, Federal Environment Agency (UBA), Wörlitzer Platz 1, 06844 Dessau-Roßlau, Germany. ${ }^{4}$ Section Chemicals, Federal Environment Agency (UBA), Wörlitzer Platz 1, 06844 Dessau-Roßlau, Germany. ${ }^{5}$ Section Pharmaceuticals, Washing and Cleaning Agents, Federal Environment Agency (UBA), Wörlitzer Platz 1, 06844 Dessau-Roßlau, Germany.

Received: 21 November 2013 Accepted: 22 April 2014

Published: 12 May 2014

\section{References}

1. EC: Regulation (EC) No 1907/2006 of the European Parliament and of the Council of 18 December 2006 concerning the Registration, Evaluation, Authorisation and Restriction of Chemicals (REACH), establishing a European Chemicals Agency, amending Directive 1999/45/EC and repealing Council Regulation (EEC) No 793/93 and Commission Regulation (EC) No 1488/94 as well as Council Directive 76/769/EEC and Commission Directives 91/155/EEC, 93/67/EEC, 93/105/EC and 2000/21/EC; 2006. http://eur-lex.europa.eu/legalcontent/EN/TXT/PDF/?uri=CELEX:02006R1907-20130701\&rid=2 (last accessed 08/04/2014).

2. EC: Regulation (EC) No 1107/2009 of the European Parliament and of the Council of 21 October 2009 concerning the placing of plant protection products on the market and repealing Council Directives 79/117/EEC and 91/ 414/EEC; 2009. http://eur-lex.europa.eu/legal-content/EN/TXT/PDF/? uri=CELEX:32009R1107\&rid=2 (last accessed 08/04/2014).

3. EC: Regulation (EU) No 528/2012 of the European Parliament and of the Council of 22 May 2012 concerning the making available on the market and use of biocidal products; 2012. http://eur-lex.europa.eu/legal-content/EN/TXT/ PDF/? uri=CELEX:32012R0528\&rid=2 (last accessed 08/04/2014).

4. EC: Directive 2001/83/EC of the European Parliament and of the Council of 6 November 2001 on the Community code relating to medicinal products for human use; 2001. http://eur-lex.europa.eu/legal-content/EN/TXT/PDF/? uri=CELEX:02001L0083-20081230\&rid=6 (last accessed 08/04/2014).

5. EC: Directive 2001/82/EC of the European Parliament and of the Council of 6 November 2001 on the Community code relating to veterinary medicinal products; 2001. http://eur-lex.europa.eu/legal-content/EN/TXT/PDF/? uri=CELEX:02001L0082-20090306\&rid=3 (last accessed 08/04/2014).

6. Moermond CTA, Janssen MPM, de Knecht JA, Montforts MHMM, Peijnenburg WJGM, Zweers PGPC, Sijm DTHM: PBT Assessment using the revised Annex XIII of REACH - a comparison with other regulatory frameworks. IEAM 2011, 8(2):359-371. http://onlinelibrary.wiley.com/doi/ 10.1002/ieam.1248/abstract (last accessed 08/04/2014).

7. EC: Commission regulation (EU) No 253/2011 of 15 March 2011 amending Regulation (EC) No 1907/2006 of the European Parliament and of the Council on the Registration, Evaluation, Authorisation and Restriction of Chemicals (REACH) as regards Annex XIII; 2011. http://eur-lex.europa.eu/legal-content/ EN/TXT/PDF/?uri=CELEX:32011R0253\&rid=1 (last accessed 08/04/2014).

8. European Chemicals Agency: Guidance on information requirements and chemical safety assessment. Chapter R.76: Endpoint specific guidance; 2012:1-234. http://echa.europa.eu/documents/10162/13632/ information_requirements_r7b_en.pdf. 
9. European Chemicals Agency: Guidance on information requirements and chemical safety assessment. Part C: PBT Assessment; 2011. http://echa.europa. eu/documents/10162/13643/information_requirements_part_c_en.pdf.

10. European Medicines Agency: Guidance on the assessment of persistent, bioaccumulative and toxic (PBT) or very persistent and very bioaccumulative (vPvB) substances in veterinary medicine. European Medicines Agency, Committee for Medicinal Products for Veterinary Use (CVMP), EMA/CVMP/ERA/52740/2012; 2012. http://www.ema.europa.eu/ema/pages/includes/document/ open_document.jsp?webContentld=WC500130368 (last accessed 08/04/2014).

11. Directorate General for Health and Consumer Affairs (DG SANCO): Working Document on "Evidence needed to identify POP, PBT and VPVB Properties for Pesticides", Brussels, 25.09.2012 - rev. 3, European Commission, Health and Consumers Directorate-General, Safety of the Food chain, Chemicals, contaminants, pesticides. http://ec.europa.eu/food/plant/pesticides/approval_active_substances/docs/ wd_evidence_needed_to_identify_pop_pbt_vpvb_properties_rev3_en.pdf (last accessed 08/04/2014).

12. Roberts G: 'Large part' of registration dossiers a concern, says ECHA. Chemical Watch, 27 February 2013, http://chemicalwatch.com/13957/large-part-ofregistration-dossiers-a-concern-says-echa?q=registration\%20dossier\% 20quality (last accessed on 07/03/2014).

13. European Chemicals Agency: Facts \& Figures. Quality information is required to comply with REACH. EVALUATION REPORT 2012 - MAIN OUTCOMES AND KEY RECOMMENDATIONS FOR INDUSTRY. February 2013, http://echa.europa. eu/documents/10162/13628/evaluation_report_summary_2012_en.pdf (accessed 07/03/2014).

14. European Chemicals Agency: Practical guide 2: How to report weight of evidence; 2010. http://echa.europa.eu/documents/10162/13655/pg_report_weight_of_ evidence_en.pdf, (accessed 26/06/2012).

15. Boethling R, Fenner K, Howard P, Meylan W, Klečka G, Madsen T, Snape JR: Environmental Persistence of Organic Pollutants: Guidance for development and Review of POP Risk Profiles. IEAM 2009, 5(4):539-556. http://onlinelibrary.wiley.com/doi/10.1897/IEAM_2008-090.1/abstract (last accessed on 08/04/2014).

16. OECD: Aerobic and Anaerobic Transformation in Soil. OECD Guidelines for the Testing of Chemicals Nr. 307. Paris; 2002. http://www.oecd-ilibrary.org/ environment/test-no-307-aerobic-and-anaerobic-transformation-in-soil_ 9789264070509-en (last accessed on 08/04/2014).

17. OECD: Aerobic and Anaerobic Transformation in Aquatic Sediment Systems. OECD Guideline for the Testing of Chemicals Nr. 308. Paris; 2002. http://www.oecdilibrary.org/environment/test-no-308-aerobic-and-anaerobic-transformation-inaquatic-sediment-systems_9789264070523-en (last accessed on 08/04/2014).

18. OECD: Aerobic Mineralisation in Surface Water - Simulation Biodegradation Test. OECD Guidelines for the Testing of Chemicals Nr. 309. Paris; 2004. http:// www.oecd-ilibrary.org/environment/test-no-309-aerobic-mineralisation-insurface-water-simulation-biodegradation-test_9789264070547-en (last accessed on 08/04/2014).

19. FOCUS: Guidance Document on Estimating Persistence and Degradation Kinetics from Environmental Fate Studies on Pesticides in EU Registration. Sanco/10058/2005, version 2.0, June 2006, and Generic Guidance for Estimating Persistence and Degradation Kinetics from Environmental Fate Studies in Pesticides in EU Registration (version 1.0): document based on the official guidance document of FOCUS Degradation Kinetics in the context of 91/414/EEC and Regulation (EC) No 1107/2009; 2006. http://focus.jrc.ec. europa.eu/dk/doc.html (last accessed 08/04/2014).

20. OPPTS 835.3300 Soil Biodegradation: Fate, Transport and Transformation Test Guidelines. United States Environmental Protection Agency, Prevention, Pesticides and Toxic Substances (7101). EPA712-C-98-088, January 1998. http://www.regulations.gov/\#!documentDetail;D=EPA-HQ-OPPT-2009-01520025 (last accessed 08/04/2014).

21. EC: Technical Guidance Document on Risk Assessment in support of Commission Directive 93/67/EEC on Risk Assessment for new notified substances, Commission Regulation (EC) No 1488/94 on Risk Assessment for existing substances and Directive 98/8/EC of the European Parliament and of the Council concerning the placing of biocidal products on the market - Part Il; Publication No. 20418/EN/2; 2003. http:// ihcp.jrc.ec.europa.eu/our_activities/public-health/risk_assessment_of_Biocides/doc/ tgd (last accessed 08/04/2014).

22. European Medicines Agency: Guidance on the assessment of persistent, bioaccumulative and toxic (PBT) or very persistent and very bioaccumulative (VPVB) substances in veterinary medicine. London, UK: Rapport nr. EMA/CVMP/ERA 52740/2012; 2012. http://www.ema.europa.eu/docs/en_GB/document_library/ Scientific_guideline/2012/07/WC500130368.pdf (last accessed 08/04/2014).
23. European Food Safety Authority: Guidance for evaluating laboratory and field dissipation studies to obtain DegT50 values of plant protection products in soil. Scientific opinion of the panel on Plant Protection Products and their Residues (PPR). EFSA J 2010, 8(12):1936. http://www efsa.europa.eu/de/efsajournal/doc/1936.pdf (last accessed 08/04/2014).

24. OECD: Ready Biodegradability. OECD Guidelines for the Testing of Chemicals Nr. 301. Paris; 1992a. http://www.oecd-ilibrary.org/environment/test-no-301ready-biodegradability_9789264070349-en (last accessed 08/04/2014).

25. OECD: Ready Biodegradability - CO2 in sealed vessels (Headspace Test). OECD Guidelines for the Testing of Chemicals Nr. 310. Paris; 2006. http://www.oecdilibrary.org/environment/test-no-310-ready-biodegradability-co2-in-sealedvessels-headspace-test_9789264016316-en (last accessed 08/04/2014).

26. European Chemicals Agency: Guidance on information requirements and chemical safety assessment. Chapter R.11: PBT Assessment. http://echa.europa. eu/documents/10162/13632/information_requirements_r11_en.pdf.

27. ECETOC: Understanding the Relationship between Extraction Technique and Bioavailability, Technical Report No. 117, ECETOC, Brussels, May 2013, ISSN-0773-8072117 (print), ISSN-2079-1526-117 (online); 2013. http//www.ecetoc.org/index.php? mact=MCSoap,cntnt01,details,0\&cntnt01by_category=22\&cntnt01 order_by=date\% 20Desc\&cntnt01 template=display_list_v2\&cntnt01 display_template=display_ details_v2\&cntnt01document_id=7315\&cntnt01 returnid=59 (last accessed 08/ 04/2014).

28. ECETOC: Development of interim guidance for the inclusion of non- extractable residues (NER) in the risk assessment of chemicals, Technical Report No. 118, ECETOC, Brussels, May 2013, ISSN-0773-8072-118 (print), ISSN-2079-1526-118 (online); 2013. http://www.ecetoc. org/index.php?mact=MCSoap,cntnt01,details,0\&cntnt01by_category=22\&cntnt01 order_by=date\%20Desc\&cntnt01 template=display_list_v2\&cntnt01display_template= display_details_v2cntnt01document\&_id=7316\&cntnt01 returnid=59 (last accessed 08/ 04/2014).

29. Eschenbach A, Oing K: Erarbeitung eines gestuften Extraktionsverfahrens zur Bewertung gebundener Rückstände, Gutachten.. Dessau-Roßlau: Umweltbundesamt; 2013. project number 22582.

30. Klecka GM, Muir DCG: Science-based guidance and framework for the evaluation and identification of PBTs and POPs: summary of a SETAC Pellston workshop. Summary of the SETAC Pellston Workshop on Science-Based Guidance and Framework for the Evaluation and Identification of PBTs and POPS. SETAC Pellston Workshop on Science-Based Guidance and Framework for the Evaluation and Identification of PBTS and POPS; 2008 Jan 28-Feb 1; Pensacola Beach, FL. Pensacola (FL): Society of Environmental Toxicology and Chemistry (SETAC); 2008. http://c.ymcdn.com/sites/www.setac.org/resource/resmgr/ publications_and_resources/pbtpopsexecutivesummary.pdf (last accessed 08/04/2014).

31. Gobas FAPC, de Wolf W, Burkhard LP, Verbruggen E, Plotzke K: Revisiting Bioaccumulation Criteria for POPs and PBT Assessments. IEAM 2009, 5(4):624-637.

32. Ehrlich $G$, Jöhncke $U$, Drost $W$, Schulte $C$ : Problems faced when evaluating the bioaccumulation Potential of substances under REACH. IEAM 2011, 7(4):550-558.

33. OECD: Bioaccumulation in Fish: Aqueous and Dietary Exposure. OECD Guideline for the Testing of Chemicals Nr. 305. Paris; 2012. http://www.oecdilibrary.org/environment/test-no-305-bioaccumulation-in-fish-aqueous-anddietary-exposure_9789264185296-en (last accessed 08/04/2014).

34. OECD: Guidance document on the use of the harmonised system for the classification of chemicals which are hazardous for the aquatic environment. OECD series on testing and assessment Number 27. Paris; 2001. http://search. oecd.org/officialdocuments/displaydocumentpdf/?cote=env/jm/mono(2001) 8\&doclanguage=en (last accessed 08/04/2014).

35. Crookes M, Brooke D: Estimation of fish bioconcentration factor (BCF) from depuration data, Product Code: SCHO0811BUCE-E-E. Bristol, UK: Environment Agency; 2011. https://www.gov.uk/government/uploads/system/uploads/ attachment_data/file/291527/scho0811buce-e-e.pdf.

36. POP-Convention: Stockholm Convention on Persistent Organic Pollutants. May 22nd; 2001. http://chm.pops.int/Portals/0/download.aspx?d=UNEP-POPS-COPCONVTEXT.En.pdf (last accessed 08/04/2014).

37. United States Environmental Protection Agency; Prevention, Pesticides and Toxic Substances (7101): OPPTS 850.1710. Oyster BCF: Ecological Effects Test Guidelines. EPA712-C-96-127; 1996. http://www.epa.gov/opptsmnt/pubs/frs/publications/ OPPTS_Harmonized/850_Ecological_Effects_Test_Guidelines/Drafts/850-1710.pdf.

38. OECD: Bioaccumulation in Sediment-dwelling Benthic Oligochaetes. OECD Guideline for the Testing of Chemicals Nr. 315. Paris; 2008. http://www.oecdilibrary.org/environment/test-no-315-bioaccumulation-in-sediment-dwellingbenthic-oligochaetes_9789264067516-en (last accessed 08/04/2014). 
39. OECD: Bioaccumulation in Terrestrial Oligochaetes. OECD Guideline for the Testing of Chemicals Nr. 317. Paris; 2010. http://www.oecd-library.org/ environment/test-no-317-bioaccumulation-in-terrestrial-oligochaetes_ 9789264090934-en (last accessed 08/04/2014).

40. Pérez-Fuentetaja A, Lupton S, Vlapsadl M, Samara F, Gatto L, Biniakewitz R, Aga DS: PCB and PBDE levels in wild common carp (Cyprinus carpio) from eastern Lake Erie. Chemosphere 2010, 81(4):541-547. http://www.sciencedirect. com/science/article/pii/S0045653510007071 (last accessed 08/04/2014).

41. Parkerton TF, Arnot JA, Weisbrod AV, Russom C, Hoke RA, Woodburn K, Traas TP, Bonnell M, Burkhard LP, Lampi MA: Guidance for evaluating in vivo fish bioaccumulation data. IEAM 2008, 4(2):139-155. http://onlinelibrary.wiley.com/ doi/10.1897/IEAM_2007-057.1/abstract (last accessed 08/04/2014).

42. Weisbrod AV, Woodburn KB, Koelmann AA, Parkerton TF, McElroy AE, Borgå K: Evaluation of bioaccumulation using in vivo laboratory and field studies. IEAM 2009, 5(4):598-623. http://onlinelibrary.wiley.com/doi/10.1897/ IEAM_2009-004.1/full (last accessed 08/04/2014).

43. Martin JW, Mabury SA, Solomon KR, Muir DCG: Bioconcentration and tissue distribution of perfluorinated acids in rainbow trout (Oncorhynchus mykiss). Environ Toxicol Chem 2003, 22:196-204

44. Conder JM, Hoke RA, de Wolf W, Russell MH, Buck RC: Are PFCAs bioaccumulative? A critical review and comparison with regulatory criteria and persistent lipophilic compounds. Environ Sci Technol 2008, 42:995-1003.

45. Veith GD, Defoe DL, Bergstedt BV: Measuring and estimating the bioconcentration factor of chemicals in fish. J Fish Res Board Canada 1979, 36:1040-1048.

46. Bintein S, Devillers J, Karcher W: Nonlinear dependance of fish biocencentration on n-octanol/water partition coefficient. SAR QSAR Environ Res 1993, 1993(1):29-39.

47. Nichols JW, Fitzsimmons PN, Burkhard LP: In vitro-in vivo extrapolation of quantitative hepatic biotransformation data for fish. II. Modeled effects on chemical bioaccumulation. Environ Toxicol Chem 2007, 26(6):1304-1319.

48. HESI: HESI Bioaccumulation Project Committee Workshop Summary "Moving Bioaccumulation Assessments to the Next Level: Progress Made and Challenges Ahead. Alexandria, VA, USA: ILSI Health and Environmental Sciences Institute; 2011. http://www.hesiglobal.org/files/public/Committees/ Bioaccumulation/BioacWkshpSummary070811.pdf (accessed 11/01/2012).

49. EEC: Council Directive 67/548/EEC of 27 June 1967 on the approximation of laws, regulations and administrative provisions relating to the classification, packaging and labelling of dangerous substances; 1967. http://eur-lex.europa. eu/legal-content/EN/TXT/PDF/?uri=CELEX:31967L0548\&rid=1.

50. EC: Regulation (EC) No 1272/2008 of the European Parliament and of the Council of16 December 2008 on classification, labelling and packaging of substances and mixtures, amending and repealing Directives 67/548/EEC and 1999/45/EC, and amending Regulation (EC) No 1907/2006; 2008. http://eur-lex.europa.eu/legalcontent/EN/TXT/PDF/?uri=CELEX:02008R1272-20110419\&rid=2.

51. OECD: Earthworm Reproduction Test (Eisenia fetida/Eisenia andrei). OECD Guidelines for the Testing of Chemicals Nr. 222. Paris; 2004b. http://www. oecd-ilibrary.org/environment/test-no-222-earthworm-reproduction-testeisenia-fetida-eisenia-andrei_9789264070325-en (last accessed 08/04/2014).

52. European Commission: 4th Report on the implementation of the Community Strategy for Endocrine Disrupters a range of substances suspected of interfering with the hormone systems of humans and wildlife (COM (1999) 706); 2011. http://ec.europa.eu/environment/chemicals/endocrine/pdf/sec_2011_1001.pdf.

53. Frische T, Bachmann J, Frein D, Juffernholz T, Kehrer A, Klein A, Maack G, Stock F, Stolzenberg H-C, Thierbach C, Walter-Rohde S: Identification, assessment and management of "endocrine disruptors" in wildlife in the EU substance legislation-Discussion paper from the German Federal Environment Agency (UBA). Toxicol Lett 2013, 223(2013):306-309. http://www.sciencedirect. com/science/article/pii/S0378427413001021 (last accessed 07/04/2014).

54. Ng CA, Scheringer M, Fenner $\mathrm{K}$, Hungerbuhler $\mathrm{K}$ : A framework for evaluating the contribution of transformation products to chemical persistence in the environment. Environ Sci Technol 2011, 45(1):111-117. http://pubs.acs.org/doi/abs/10.1021/es1010237 (last accessed 07/04/2014).

doi:10.1186/2190-4715-26-9

Cite this article as: Rauert et al:: Proposal for a harmonised PBT

identification across different regulatory frameworks. Environmental Sciences Europe 2014 26:9.

\section{Submit your manuscript to a SpringerOpen ${ }^{\circ}$ journal and benefit from:}

- Convenient online submission

- Rigorous peer review

- Immediate publication on acceptance

- Open access: articles freely available online

- High visibility within the field

- Retaining the copyright to your article

Submit your next manuscript at $\gg$ springeropen.com 